DOI https://doi.org/10.36059/978-966-397-233-6-4

Оксана Салата

\title{
Роль 3МІ у творенні міфів та дезінформації населення окупованих територій України
}

\author{
The role of the mass media in creating myths \\ and disinformation of the population \\ of the occupied territories of Ukraine
}

The role of the mass media in spreading myths created by Nazi propaganda over the occupied territories of Ukraine during the Soviet-German War, 1941-1944, is shown.

It is shown that during the Second World War, the mass media possessed the necessary technologies and methods to influence the public consciousness, and the Nazi and Soviet authorities skillfully used it to spread their ideologies and myths.

It has been revealed that the occupation administration used various forms of propaganda through the publication of newspapers and journals in Ukrainian; demonstration of special films in cinemas; visual agitation in the form of posters and leaflets, as well as documentary exhibitions; theatrical performances; radio broadcasts in Ukrainian, Russian and other languages.

The activities of the propaganda bodies of Nazi Germany and the occupying power on the formation of myths about the future of Great Germany, which would ensure the well-being and happy life of all peoples; spreading the myth of the liberation of the USSR peoples from "Bolshevism" has been revealed. It is shown that the struggle against the Soviet political and social system was the central point of this myth. It is stated that one of the most important issues in the occupation press was the Jewish question. The periodical press in the occupied territories not only informed the population about the measures taken by the occupying power, but also directly influenced the change in the attitude of the local population towards Jews. Myths about the crimes of the Jewish population created by the Nazi authorities were spread through the press.

In general, the mass media representing the occupying power made great efforts to divert the attention of the local population from the real affairs both at the front and in the rear of the German army. Disinformation measures had an influence only at the beginning of the occupation, but the population quickly lost faith and stopped trusting the occupying power. 
Засоби масової інформації (ЗМI) є одним із найвпливовіших інструментів формування суспільної свідомості. Це добре розуміли керівники Третього рейху та Радянського Союзу, використовуючи ЗМІ для впливу на свідомість населення окупованих територій, зокрема, й населення України.

Під час Першої та Другої світових воєн ЗМІ вже були відчутним фактором впливу на суспільну свідомість, і чи не найвпливовішою стратегією такого впливу можна назвати міфологізацію - цілеспрямоване введення суспільства та окремих людей в ілюзорну модель реальності.

Починаючи з Першої світової війни, засоби масової інформації, зокрема газети і листівки, завжди були активними чинниками збройних конфліктів. У цьому контексті можна розглядати міф, що став приводом для Другої світової війни, - напад на радіостанцію в Глейвіце. Радіо стало засобом, який використала фашистська Німеччина, а газети - інструментом, завдяки якому було створено і розповсюджено цей міф.

Важливу роль преси в маніпуляції суспільною свідомістю розумів також лідер італійських фашистів Беніто Муссоліні. За спогадами його соратників, у процесі планування військових операцій іноді він більше уваги приділяв тому, які заголовки з'являться в газетах, аніж власне військовій доцільності згаданих операцій.

Уже наприкінці 20-х років XX ст. лідери німецької Націонал-соціалістичної партії розуміли, що періодичні видання та радіо можуть стати одним із найпотужніших засобів боротьби за встановлення в Німеччині нацистського режиму. Щойно прийшовши до влади, Гітлер оголосив пресу Третього Рейху об’єктом політики гляйхшалтунг (Gleichschaltung - нацистська політична концепція підкорення всіх сфер життя Німеччини інтересам націонал-соціалістичного режиму). Одразу ж після утворення Міністерства народної освіти і пропаганди Німеччини, яке очолив Й. Геббельс, усі газети, журнали та радіомовлення Третього Рейху опинилися під жорстким контролем. Внаслідок розробки закону про пресу, прийнятого 4 жовтня 1933 р., усі опозиційні нацистському режиму видання було заборонено. Цей закон позбавив видавців права приймати самостійні рішення в галузі 
редакційної політики. Такі права передавалися редакторам, які були, на думку керівництва Рейху, “носіями суспільних інтересів”. Саме тому 1935 року було розповсюджено наказ про обов'язкове членство журналістів у Націонал-соціалістичній робітничій партії Німеччини (НСДАП) (Волковський Н., 2003, с. 192).

Уже в перший рік перебування при владі гітлерівського керівництва, у Німеччині виник періодичний друк, концептуально уніфікований, підпорядкований нацистській політиці та економічним потребам. Кількість нацистських газет щороку збільшувалася. Про це свідчать такі дані: 1932 р. за ініціативою Націонал-соціалістичної робітничої партії виходило 70 друкованих видань, 1935 р. партія вже мала 140 газет, 1944 р. їх було 352 газети (История Второй Мировой войны, 1974, c. 303).

Не менш важливу роль відігравала періодична преса та друковані матеріали на окупованих німецькою армією територіях. Крім військ вермахту, заповнювало інформаційний вакуум в зайнятих областях Міністерство східних окупованих територій, у якому для цього були створені спеціальні структури та відділи. Структура міністерства передбачала в розпорядженні рейхскомісарів спеціальні відділи пропаганди. До цієї системи були також включені нижчі підрозділи окупаційної адміністрації - старости, бургомістри та інші службові чини. Структура забезпечувала заклади районних і волосних управ, сільських старост пропагандистськими матеріалами. Якщо до села газети та листівки не доходили, то старости зобов'язувалися приносити їх і читати самостійно. Було вироблено спеціальний порядок читання зведень Німецького Верховного Командування населенню. Щоб необхідна інформація постійно супроводжувала кожного мешканця міст і сіл, в найбагатолюдніших місцях встановлювалися спеціальні дошки. На ці ж дошки вивішували плакати і листівки.

У Міністерстві східних окупованих територій було створено чітку систему організації функціонування як німецької, так і окупаційної преси та забезпечення її необхідними матеріалами. Керівником цього відділу був міністеріалдиригент Циммерман, а секретарем - Людвиг Булиш. Цей відділ опікувався 
забезпеченням пропагандистів обладнанням, кіноматеріалами, папером для газет, гучномовцями тощо ${ }^{1}$.

Досить впливовим було й новостворене Політичне управління пресою. Воно опікувалося розробкою чітких інструкцій 3 цензури для видавців періодики. Тут обслуговували кореспондентів східної преси. Саме в цьому відділі формувалися міфи про неперевершену Великонімеччину, яка несе усім народам добробут та забезпечене життя; друкувалися яскраві пропагандистські путівники по Німеччині, у яких розповідалося про найкращу у світі країну, брошури та книжки про Адольфа Гітлера та його прагнення створити нову Європу, про німецьких селян та робітників, які живуть у достатку².

Основним завданням окупаційної преси (як і інших форм нацистської пропаганди) було поширення міфу про “звільнення” народів СРСР від більшовизму. Центральним пунктом цього міфу була боротьба з радянським політичним і суспільним ладом.

Про те, наскільки важливими були періодичні видання, свідчить той факт, що наприкінці 1941 р. у директиві рейхсміністра Розенберга про запровадження окупаційного режиму в окупованих радянських областях зазначалося, що всі питання, пов'язані з дозволом випуску місцевих газет, розв'язуються рейхсміністром у справах окупованих східних областей на основі пропозицій рейхскомісарів. Наголошувалося, що газет потрібно видавати стільки, скільки це необхідно для того, щоб не залишати населення без необхідної інформації. Але водночас слід прагнути до обмеження кількості місцевих газет у рейхскомісаріатах. Далі зазначалося, що дозвіл на видання місцевих газет залежить ще й від наявності в кожному окремому випадку політично надійних видавців та редакторів. Необхідною умовою $€$ наявність достатньої кількості німецьких цензурних

${ }^{1}$ Державний Російський воєнний архів (ДРВА). Фонд 1358. Імперське міністерство у справах окупованих східних областей (м. Берлін), (Німецькі архіви. Трофейні документи): Оп. 1. Спр. 1. Арк. 38.

${ }^{2}$ ДРВА. Фонд 1358. Імперське міністерство у справах окупованих східних областей (м. Берлін), (Німецькі архіви. Трофейні документи): Оп. 1. Спр. Арк. 22 
органів (Німецько-фашистський окупаційний режим на Україні... 1963 , с. 65-66).

У кожному гебітскомісаріаті, області, районі було створену органи цензурного нагляду за періодикою. Із листа комісара Умані генеральному комісару ми бачимо, що всі статті та публікації, які публікувалися в уманській газеті “Український голос", піддавалися прискіпливій цензурі з боку відділів пропаганди окупаційної адміністрації на місцях. Листи, що надходили від громадян, також проходили прискіпливу цензуру, а деякі так і не потрапляли до газети ${ }^{1}$.

Для міських жителів преса була основним джерелом інформації, а місцеве радіо регулярно передавало ї̈ докладні огляди. Підбірки газет також були доступні читачам міських бібліотек. Популярність преси серед населення була зумовлена регулярними публікаціями зведень про становище на фронтах Другої світової війни, а також розпоряджень і наказів місцевої адміністрації. Періодичні видання читали та обговорювали мільйони людей на окупованій території.

Надзвичайно важливим у висвітленні окупаційною пресою було єврейське питання. Періодична преса на окупованій території не лише інформувала населення про заходи окупаційної влади, а й безпосередньо впливала на зміну ставлення місцевого населення до євреїв. Саме преса поширювали нацистські міфи про злочини представників єврейського населення. На жаль, іноді це мало вирішальне значення при наданні їм необхідної допомоги (Гитлеровская пропаганда юдофобии в прокламациях и карикатурах, 2005, с. 56-58).

3 метою уніфікації та систематизації періодичних видань на території Рейхскомісаріату “Україна" відділом преси Міністерства східних окупованих територій було розроблено складну, але чітку систему підрозділів. Один із них, зокрема “Німецьке видавничо-друкарське товариство в Україні з обмеженою відповідальністю”, що розміщалось у Луцьку, стало головним. Це видання відповідало, за випуск німецькомовної періодики, а також офіційних бюлетенів рейхскомісара

${ }^{1}$ Центральний державний архів вищих органів влади та управління України (далі - ЦДАВОУ): Фонд 2. - Рада міністрів України РСР: Оп. 2. Спр. 74. Арк. 4. 
та генерал-комісарів, книготоргівлею і мало у своїй структурі кореспондентів і фотографів. Безпосередньо періодикою в різних регіонах опікувалися створені при "Німецькому видавничо-друкарському товаристві в Україні” та підпорядковані йому товариства “Преса України”, “Українія”, “Ужитковий друк України”, сільськогосподарське видавництво України.

Товариство “Преса України” фактично було утворене 1 грудня 1941 р. тими ж засновниками, що й “Німецьке видавничо-друкарське товариство”. Директором його також став Г. Грорнауер. Товариство координувало роботу всіх підприємств та друкарень у Рейхскомісаріаті України та в зоні військової адміністрації, контролювало їх господарчу діяльність, забезпечувало необхідними матеріалами та ін. Товариство "Українія" також було засноване в Луцьку (листопад 1941 р.) Національною спілкою німецьких видавців газет у Берліні. На початку 1943 р. цей відділ преси мав 32 власні пункти розповсюдження. А в серпні цього ж року періодичні видання розповсюджувалися вже в 65 містах.

Загалом, на початку 1943 р. товариство “Преса України” вже координувала і забезпечувала випуск 91 газети загальним разовим накладом близько 1 млн примірників. Таким чином, за підрахунками вчених, які досліджували окупаційну пресу, на території Рейхскомісаріату “Україна” видавалося близько 300 газет та часописів (Черняков Б., 2006, с. 57-58). Дозвіл на таку кількість періодичних видань можна пояснити прагненням нацистської адміністрації повністю контролювати інформаційне поле окупованих територій, поширювати необхідну інформацію пропагандистського характеру і таким чином впливати на свідомість та поведінку місцевого населення.

Газети та часописи, що виходили на окупованій території, видавалися багатьма мовами. Більшість із них видавалася накладом від 2,5 до 10 тисяч примірників. Газети, що видавалися на території Рейхскомісаріату “Україна” та зони військової адміністрації видавалися переважно українською, іноді російською мовами та мовою багаточисленних національних меншин, які жили в цей період в Україні (Волковський Н., 2003, с. 202). 
Більшість газет і часописів, що видавалися на окупованій території, не дуже відрізнялися одне від одного за змістом і характером публікацій. На перших сторінках друкувалися, як правило неправдиві відомості про переможні зведення з фронтів та возвеличення німецьких солдатів, їх доблесті. На другій та третій сторінках публікувалися, переважно, статті про більшовицький режим та його ворожі наміри щодо українців, про відомих українських діячів минувшини, про досягнення українських селян в умовах окупації. Більшість репортажів подавалася через призму поглядів німецьких журналістів або українських журналістів, які співпрацювали з окупаційною владою. Це накладало певний ідеологічний і психологічний відбиток на читача.

Показовими в цьому аспекті $€$ заголовки статей у часописі "Волинь" та "Вінницькі вісті": "Київ і Полтава визволені!”1, "Успіх на Донецькому фронті"2, "Німецькі війська успішно стримують ворожий натиск”. У цих статтях говориться про те, що німецько-фашистська армія успішно протистоїть радянським військам на північному заході Кіровоградської області ${ }^{3}$. Цікаво, що в ці ж дні - 23-24 листопада 1941 р. - у радянських зведеннях читаємо, що радянські війська взяли районний центр Кіровоградської області, Онуфріївку. У районі нижньої течії річки Прип'ять, продовжуючи наступ, вони також захопили районний центр Поліської області з містом Хойники (Жадов А.) ${ }^{4}$. Яка ж інформація правдива? Як себе почуває населення окупованих територій, отримавши інформацію водночас з німецьких і радянських зведень?

Згідно з концепцією окупаційних газет, складається враження, нібито німецько-фашистська армія, справді, принесла народу України мир та злагоду. У пресі створювався міф про непереможність німецької армії, розвінчувався радянський

${ }^{1}$ Волинь. 1941. 12 вересня. С. 1.

${ }^{2}$ Волинь. 1942. 12 лютого. С. 1.

${ }^{3}$ Волинь. 1943. 25 листопада. С. 1.

${ }^{4}$ Жадов A.C. Четыре года войны. URL: http://militera.lib.ru/memo/russian/ zhadov_as/05.html/ 
режим, а також протиставлявся німецькому. У газеті “Вінницькі вісті" на першій сторінці читаємо "Німеччина перемагає на всіх фронтах"1, на другій та третій сторінках бачимо публікації “Пробудження до нового життя", “Правдиве обличчя більшовизму"3 та ін. Усі ці публікації були спрямовані на створення в населення окупованих територій України позитивного образу нацистської Німеччини та німецького солдата.

У більшості публікацій робився акцент на риси, що різняться в керівництві та умовах життя населення окупованих територій. Так у газеті “Сумський вісник” № 6 від 5 листопада 1941 р. писали: "Непереможна німецька армія принесла місту Суми справжню свободу, звільнивши його від комуністичного іга. Тільки недавно громадяни міста почали дихати на повні груди...”. У газеті “Нова Україна” від 6 березня 1942 р., що видавалася на Харківщині, опубліковано статтю “Ліквідація більшовицької колгоспної системи”, де зазначається, що, на відміну від більшовиків, німецький уряд видав наказ про надання селянам землі в одноосібне користування ${ }^{5}$. Тут же розповідається про те, як важко жилося українським селянам, а тепер, завдяки "новому порядку” та новому земельному закону, селяни зможуть стати заможними та забезпечувати Великонімецьку державу. Однак земельний закон так і залишився лише на папері. Колгоспна система продовжувала існувати в іншому форматі, адже це була дуже зручна форма господарювання, в умовах якої можна було повністю контролювати працю селян та вилучати більшу частину виробленої продукції.

Оскільки преса насамперед виконувала стратегічне завдання нацистської ідеології - сприяти тому, щоб населення окупованих територій перейнялося антисемітськими та антибільшовицькими настроями, - значне місце в періодичній пресі відводилося саме

${ }^{1}$ Вінницькі вісті. 1941. № 16. С. 1.

${ }^{2}$ Вінницькі вісті. 1941. № 14. С. 3.

${ }^{3}$ Вінницькі вісті. 1942. № 63. С. 2.

${ }^{4}$ Сумський віник. 1941. № 6. С. 2.

${ }^{5}$ Державний Архів Харківської області (далі - ДАХО): Фонд 2984 - Редакція газети «Нова Україна»: Оп. 1. Спр. 1. Арк. 54-65. 
єврейському питанню. Більше того, єврейство ототожнювалося з більшовизмом та Радянською владою". Так, в газеті “Вінницькі вісті” від 9 серпня 1942 р. під заголовком “Правдиве обличчя більшовизму” зображено карикатуру, на якій показано, як єврей знімає маску Сталіна, і коментується це так, що насправді Радянською країною керують євреї, а Сталін $є$ їхньою маскою².

“Єврейське питання" займало досить помітне, а для ряду видань ледь не центральне місце в антирадянській пропаганді. У редакційних статтях та пропагандистських матеріалах, які готувались у Берліні, а також регулярно публікованих промовах і виступах керівників нацистської Німеччини, червоною лінією проходила думка, що саме євреї як опора більшовицького режиму є головними ворогами не лише Німеччини, а й інших народів СРСР.

Нерідко авторами антисемітських публікацій ставали й самі редактори газет та часописів. Окрім професійних журналістів, залучалися також і ті, хто хотів, присвятити свої статті антирадянській та антисемітській тематиці. Серед них були історики, мистецтвознавці, лікарі, музикознавці та ін.

Практично всі газети, що видавалися на території Рейхскомісаріату "Україна" та в зоні військової адміністрації, на останній сторінці свого видання публікували спеціальні розпорядження окупаційних властей, що стосувалися євреїв. Публікувалася також величезна кількість матеріалів про переслідування євреїв у всі часи і в усіх державах світу; наводилися цитати 3 антисемітських висловів відомих філософів і політиків. Тобто формувалося ідеологічне підгрунтя антисемітизму на українських землях. Створювалась картинка про те, що єврейське населення переслідується ледь не всім світом.

Необхідно зазначити, що таких публікацій особливо багато з'явилося саме наприкінці 1943 р., після поразки німецькофашистської армії під Сталінградом. Гітлерівське керівництво ще плекало надію переконати населення окупованих територій у тому, що з боку єврейського народу та більшовицького керівництва їм загрожує велика небезпека.

\footnotetext{
${ }^{1}$ Вінницькі вісті. 1943. № 56. С. 3.

${ }^{2}$ Вінницькі вісті. 1942. № 63. С. 3.
} 
Періодичні видання використовували також для виховання молодих людей, що залишились на окупованій території. Як підтвердження розглянемо декілька типових газет, що виходили на окупованій гітлерівською армією території, зокрема 88 число газети “Нове Запоріжжя” від 4 жовтня 1942 р. На 3-й сторінці читаємо статтю “Виховання молоді”, де автор дає настанови, як треба виховувати українську молодь і ставить за приклад німецьку молодь. На 4-й сторінці стаття “Кіно в цей час", у якій розповідається про те, з яким задоволенням місцеве населення переглядає німецькі кінофільми․․

У пресі друкувались статті, які показували, щоб народ добровільно бере участь у розбудові Великонімеччини, уникаючи при цьому всякого примусу. Пропагувалася співпраця, особливо в галузях соціальної, санітарної, культурної та спортивної роботи․․ Аналогічні установки свого часу давала селянам і Радянська влада. Фактично гітлерівська адміністрація через урядування закликала українське населення до повного підкорення та чіткого виконання своїх службових обов'язків.

У газеті “Сумський вісник" редактор чітко дотримується концепції висвітлення подій. Так, у першому числі цієї газети від 19 жовтня 1941 р., на 1-й сторінці, ми читаємо звернення до українського народу під заголовком "Настав великий радісний час", де автор, цитуючи Тараса Шевченка, говорить про Україну, про те, як її сплюндрували і привели до загибелі більшовики. Розкриваються великі перспективи перед українським народом: вільна торгівля, повний розвиток приватної ініціативи, дійсно вільна праця, приватна власність і повне духовне розкріпачення ${ }^{3}$. На 2-й сторінці 6-го числа цієї ж газети читаємо статтю про те, що непереможна німецька армія принесла м. Суми справжню свободу, звільнивши його від комуністичного панування, саме тепер громадяни міста почали дихати на повні груди і можуть віддатися мирній наполегливій праці ${ }^{4}$.

\footnotetext{
${ }^{1}$ Нове Запоріжжя. 1942. № 88. С. 3, 4 .

${ }^{2}$ Вінницькі вісті. 1941. № 14. С. 1-4.

${ }^{3}$ Сумський вісник. 1941. № 1. С. 1.

${ }^{4}$ Сумський віник. 1941. № 6. С. 2.
} 
Не стала винятком і газета "Нове Українське Слово”, що виходила в столиці Української РСР - Києві. 229-е число цієї газети від 30 вересня 1943 р. також повністю відповідає структурним акцентам побудови інформаційного блоку в окупаційній пресі. На 1-й сторінці, як і в переважній більшості газет, повідомлення про успішні бої німецької армії в районі Запоріжжя та про великі втрати Радянської Армії. Тут же стаття “Гарант перемоги”, де автор стверджує, що саме Радянська Армія прагнула захопити всю Європу, і лише втручання Німеччини зупинило червону навалу. Саме гітлерівська Німеччина названа в цій статті гарантом миру в Європі. У вересні 1943 р. німецько-фашистські війська відступали під натиском Радянської Армії. Тепер основним завданням гітлерівців було втриматися на окупованих територіях, тому довіра населення була їм вкрай необхідна. Тому на цій же сторінці надруковано звернення до українського народу про те, що війна знову наближається і українське населення має допомогти німецькій владі ${ }^{1}$.

Через періодичну пресу німецький окупаційний режим створював ілюзію прихильного ставлення гітлерівської влади до українського населення. Постійне наголошування на здобутках та мирній праці в ім'я Великонімеччини, публікації про те, як квітне та розвивається українська культура, постійне порівняння та протиставлення, з одного боку, німецького та, з другого боку, радянського режимів (звісно ж, не на користь останнього) призводили до того, що певна частина українського суспільства спочатку справді повірила окупаційній владі й співпрацювала з нею.

Міфічно виглядають повідомлення, розміщенні в перші дні у газетах, що видавалися в Рейхскомісаріаті “Україна”, де розповідалося про працю та здобутки українських селян. Одночасно наголошувалося на тому, що українським селянам, щоб отримати високі врожаї, необхідно вчитися, і для цього німецька влада організовує спеціальні сільськогосподарські курси.

У часописі “Волинь” від 7 вересня 1941 р. повідомляється про те, що за сприяння німецької влади на українських землях

1 Центральний державний архів громадських об’єднань України: Фонд 1 - Центральний Комітет Комуністичної партії (більшовиків) України: Оп. 22. Спр. 390. Арк. 1-2. 
розгортаються широкі можливості для підвищення кваліфікації сільськогосподарських робітників. У кожній області селяни можуть удосконалити технологію обробки землі, збільшення поголів'я великої рогатої худоби та покращити своє матеріальне становище ${ }^{1}$.

Стара радянська колгоспна система, яку німецька окупаційна влада не ліквідувала, а поставила собі на службу, усе частіше викликала невдоволення в українських селян, що відбивалося не лише на їх настроях. У зв'язку з цим на початку 1942 р. окупаційна влада проголосила реформи в аграрному секторі. До управління сільським господарством надійшов закон "Про новий аграрний лад” від 15 лютого 1942 р. Газети одразу ж відреагували, і вже 26 лютого його було опубліковано практично в усіх окупаційних виданнях. На сторінках періодичних видань було розгорнуто широку кампанію пропаганди нового земельного закону та його положень під гаслом “Кожному селянинові своя земля!” (Нестеренко В., 2004, 282). Складається враження, що реформа вже впроваджується і працює - насправді ж, німецька окупаційна адміністрація робила все, щоб відтягнути руйнування колгоспної системи.

Протягом двох-трьох місяців у газетах обговорювався “Тимчасовий статут роботи”, де містилися конкретні вказівки щодо організації нового земельного господарювання ${ }^{2}$. Активне обговорення закону створило ілюзію його впровадження, але коли селяни побачили, що реально нічого не робиться, і вони продовжують працювати в колективних господарствах, то почали відкрито виступати проти такого господарювання, що підігрівалося радянською пропагандою.

Наступним важливим питання, якому в періодичній пресі приділялася велика увага, була культура та освіта українського населення. Рідше з'являлися публікації про наукові дослідження.

3 огляду на концептуальні принципи політики гітлерівської Німеччини щодо культурного розвитку населення східних

${ }^{1}$ Волинь. 1941. 7 вересня. С. 3.

${ }^{2}$ Державний архів Сумської області. Фонд 1848 - Редакція газети «Сумський вісник», м. Суми Сумської області: Оп. 1. Спр. 2. Арк. 1-10. 
окупованих територій, зокрема українців, необхідно зазначити, що керівництво Третього Рейху не бажало заохочувати тут розвиток національної свідомості і національної культури. Зокрема щодо освіти Гіммлер зазначав, що освіта населення окупованих територій може призвести до непокори населення окупаційній адміністрації, а це не відповідає колонізаційній політиці нацистської Німеччини ${ }^{1}$.

Щоб підтримувати необхідні настрої серед населення окупованих територій, окупаційна адміністрація постійно друкувала в газетах інформацію про активність сільськогосподарських працівників, про гарні врожаї, які отримують українські селяни в колективних господарствах, про створення різноманітних організацій та гуртків, які допомагали українським селянам підвищити свій культурний і професійний рівень. У газеті “Волинь” від 7 вересня 1941 р. надруковано статтю про те, як обласний Земельний відділ окружної Управи в м. Рівному, зробивши акцент на продуктивності праці як першооснові добробуту українського селянства, зруйнованого більшовиками, розпочав організацію гуртків “Сільський господар” в кожній громаді по всій області ${ }^{2}$. Обласний відділ розпочав активну пропаганду серед населення Рівненської області і вже з перших днів своєї діяльності опублікував у цій же газеті звернення до громадян про те, що Україна завжди була багатою країною, своїми ресурсами вона підтримувала Європу. Сама ж має все, що необхідно для самостійного господарювання. Але більшовицьке керівництво використало багатства України у своїх великодержавних інтересах. Колгоспи, створені більшовиками, остаточно зруйнували українське село ${ }^{3}$.

Досить ефективно окупаційна влада використала факт відступу радянських військ з території Української РСР. У статтях розповідалося, як брутально Радянська влада, відступаючи, нищила посіви, заводи та фабрики, шахти, руйнувала водогони та залізниці, і саме тому так важко все відновити і налагодити

\footnotetext{
${ }^{1}$ Военно-исторический журнал. 1960. № 1. С. 37-42.

${ }^{2}$ Волинь. 1941.7 вересня. С. 3.

3 Там само.
} 
нормальне життя (Салата 0., 2005, с. 113-116). Німецькій окупаційній адміністрації не складало великих труднощів усе показати в газетах як інформацію для місцевого населення. Насправді ж, люди й самі бачили, що відбувалося під час відступу більшовиків. У газеті “Нове Запоріжжя” № 109, 1942 р. у статті “Шлях до перемоги” автор пише про те, що німці, які прийшли на українську землю, були вражені вандалізмом більшовиків. Автор акцентує увагу читачів на тому, що все, що було зроблене і збудоване руками селян та робітників: залізниці, шосейні дороги, мости, переправи, кінний і автомобільний транспорт, хлібозаводи, хлібопекарні, промислові підприємства, - було безжально знищене більшовиками. I тут же автор закликає українців до співпраці з німецькою адміністрацією, закликає покірно брати на себе весь тягар відбудови сільського господарства та промисловості ${ }^{1}$. Оскільки багато людей були свідками такої “діяльності” радянських військ, окупаційна пропаганда потрапляла в благодатний грунт.

Для посилення впливу на населення практично на всіх територіях Рейхскомісаріату “Україна” та в зоні військової адміністрації було ініційовано створення суспільно-просвітницьких товариств “Просвіта” та Спілки українських письменників. Уже з жовтня 1941 р. друкуються в газетах повідомлення про те, що в містах та районних центрах створюються або відновлюють свою роботу раніше закриті товариства “Просвіта”. Читачі знайомляться з метою, заняттями та діяльністю цих товариств. Але основне, на що необхідно звернути увагу, - це те, що всі товариства були взяті окупаційною адміністрацією під свій жорсткий контроль і вся їхня діяльність повністю або регламентувалася гебітскомісаріатами, або підпорядковувалася їм. Фактично окупаційна адміністрація використовували товариство “Просвіта", як і інші суспільно-просвітницькі організації, для поширення необхідної інформації та для впливу на українське населення. Незважаючи на жорсткий контроль з боку окупаційної влади, більшість діячів “Просвіти” прагнула пробудити національну свідомість українців і допомогти вистояти їм в тяжких умовах.

\footnotetext{
${ }^{1}$ Нове Запоріжжя. 1942. № 109. С. 4.
} 
У Києві за ініціативою товариства “Просвіта” розроблявся репертуар для діючих театрів. До нього входили танці та пісні, невеликі вистави ${ }^{1}$.

При Міській управі м. Києва відділ пропаганди, у розпорядженні якого була вся культура міста, періодичні видання, кінотеатри, театри і радіо, заснував Спілку українських письменників. Очолила Спілку Олена Теліга, до неї ввійшли також Борис Вінницький та Іван Ірлявський. Спілка поставила завдання об'єднати всіх українських письменників та спрямувати їх творчу працю на користь української національної культури. Було створено власне видавництво “Культура”, підготовлено серію літературно-публіцистичних творів. За сприяння Спілки вже на третій день після захоплення Києва гітлерівськими військами почав виходити щоденник “Українське слово”, а з 19 жовтня 1941 р. - ще й літературний додаток “Література й мистецтво”, який був складовою часопису “Українське слово”2. О. Теліга зробила дуже багато для діяльності Спілки та видання газети “Українське слово”. Після арешту редакції "Українського слова" вона не брала до уваги постанов німецької влади, а продовжувала відстоювати свою позицію, ігнорувала вказівки німців зухвало й принципово.

Періодичні видання давали змогу населенню окупованих територій стежити за діяльністю товариств “Просвіти”, i, на перший погляд, картина складалася дуже втішна: ніби українці мали можливість реалізувати всі свої таланти та здібності, розбудовувати національну культуру та втілювати в життя національну ідею. Але насправді, як уже зазначалося вище, уся діяльність цієї організації жорстко контролювалася: друковані видання піддавалися жорсткій цензурі, бібліотечні фонди формувалися відповідно до вимог нового уряду, спектаклі та вечори проводилися за конкретно визначеними темами й змістом.

На сторінках окупаційної преси яскраво висвітлювалися проблеми культурного життя. Це можна пояснити тим, що окупаційна влада прагнула завоювати авторитет серед місцевого населення, особливо тієї частини української інтелігенції, яка залишилася на окупованих територіях.

\footnotetext{
${ }^{1}$ Волинь. 1942.1 січня. С. 4.

${ }^{2}$ Волинь. 1941. 26 жовтня. С. 4.
} 
Поширеною темою в місцевій періодиці стала висміювання життя людей у СРСР. У газеті “Поділля”, яка виходила в Кам'янець-Подільському було опубліковано фейлетон “Про Івана Іванова”, статті “Рай Рад”, “Картина вулиць із Москви”, де в гумористичному стилі розповідалося про життя-буття населення Радянського Союзу та його політичне становище.

В цій же газеті було опубліковано повідомлення, у якому Український комітет Кам'янець-Подільського закликав пожертвувати кошти для сімей учених міста, які були вбиті або депортовані Радянською владою ${ }^{1}$.

Один із відділів Міністерства східних окупованих територій займався виготовленням фотознімків про життя німецьких робітників і селян, російських робітників у Німеччині, які призначалися для використання в німецькій періодичній пресі для населення Німеччини, а також у газетах, що видавалися російською мовою для жителів окупованих областей СРСР. Серед них знімки робітників промислових підприємств, що стоять біля верстатів і демонструють продукцію, яку вони виготовляють; селяни, які з радістю працюють на пшеничному полі, робітники з України, які радісно працюють і проводять дозвілля: читають книжки, грають у футбол, святкують дні народження в колі друзів та ін. ${ }^{2}$

Насправді, не так легко було українським робітникам і селянам на роботах у Німеччині. Усе залежало від двох важливих факторів: місця, куди потрапляв робітник, та господаря чи керівника підприємства, на якому він працював. Зі свідчень рейхсміністра озброєнь і боєприпасів А. Шпеєра ми бачимо, як примусово перевозили робітників з усіх окупованих країн та розподіляли по підприємствах, у яких жахливих умовах їм доводилося працювати, а тих, хто порушував умови праці, відправляли до концентраційних таборів ${ }^{3}$. У своїх спогадах жителі с. Виноградне Мурованокуриловецького району

${ }^{1}$ ЦДАВОУ. Фонд 2. - Рада міністрів України РСР: Оп. 2. Спр. 68. Арк. 11-12.

2 ДРВА. Фонд 1363 - Імперське міністерство просвіти і пропаганди (м. Берлін), (Німецькі архіви. Трофейні документи): Оп. 5, Спр. 56. Арк. 7-24.

${ }^{3}$ Допрос подсудимого Шпеера. Из стенограммы заседания Международного Военного Трибунала от 21 июня 1946 года. URL: http://historic.ru/books/ item/f00/s00/z0000021/st018.shtml 
Вінницької області, яких вивезли на роботу до Німеччини, показують, що умови проживання були надзвичайно тяжкі, нелюдськими, табір, де вони жили, був обнесений чотириметровою огорожею з колючого дроту, підключеною до електромережі, щоб робітники не тікали. Годували дуже погано та ще й постійно били. Фашистські охоронці зауважували: “Ви не люди, а бидло. Чим швидше ви здохнете, тим краще і для вас, і для нас". I вмирали робітники з України щоденно. Їх вивозили візком і скидали до ями, яку часто забували навіть прикидати землею ${ }^{1}$.

Такі ж самі спогади жителів Немировського району Вінницької області, яких німці забрали до Німеччини в березні 1942 р. Розповідають, що “жили в місті Штатгарт, у бараці, де помістили 12 осіб, бо ніхто з господарів не брав на роботу. Там пробули 6 місяців. Їжа була дуже бідна: уранці - 2 брюкви та 1 кружка чаю, удень - “кирпичик” хліба на 10 осіб. Дітей, які постійно хворіли відвідував лікар, пізніше їх відправили назад додому"2.

У перший період німецько-радянської війни, завдяки поширенню міфів про “райське” життя у Німеччині, вербувальна кампанія ще якось проводилася, але вже на початку 1942 р. відправити добровільно когось із молоді чи людей старшого віку до Німеччини було практично неможливо, і тому газети стали одним із найважливіших засобів агітації та пропаганди за виїзд на роботу до цієї країни.

Крім періодичних видань, на територію Рейхскомісаріату “Україна" завозили різноманітну літературу. Книжки з фашистської Німеччини розподіляли по бібліотеках, що ще залишилися, до читалень, які відкривалися в містах, з метою розповсюдження необхідної інформації. Фактично вони ставали центрами пропаганди.

${ }^{1}$ Державний архів Вінницької області (далі - ДАВО). Фонд Р-6022. - Колекція свідчень, спогадів та інших документів колишніх в'язнів гетто, концентраційних та робочих таборів, а також громадян, примусово вигнаних до Німеччини: Оп. 1. Спр. 13. Арк. 7.

${ }^{2}$ ДФВО. Фонд Р-6022. - Колекція свідчень, спогадів та інших документів колишніх в'язнів гетто, концентраційних та робочих таборів, а також громадян, примусово вигнаних до Німеччини: Оп. 2. Спр. 17. Арк. 24. 
Таким чином, німецька окупаційна адміністрація, маючи на меті дезінформувати населення окупованих територій з метою змусити його працювати на себе, на перше місце поставила засоби масової інформації. Вона застосовувала різні форми пропаганди, видаючи газети та часописи українською мовою; демонструючи в кінотеатрах спеціальні фільми; випускаючи наочну агітацію у вигляді плакатів і листівок, а також документальних виставок; через театральні постановки, радіопередачі українською, російською та іншими мовами. Вдавалася до найсучасніших на той час методів використання преси в умовах війни.

Керівництво Третього Рейху керівництво використовувало пресу як один із дієвих засобів впливу не лише на думку, а й на свідомість населення тимчасово окупованих територій. Це також стало можливим тому, що в умовах інформаційного вакууму населення тимчасово окупованих територій СРСР потребувало новин як єдиної можливості орієнтуватись у тих складних умовах. Німецька окупаційна влада використовувала інформаційний голод, що панував після відступу радянських військ, і заповнювала інформаційний вакуум власною пропагандою та міфами.

Вінницькі вісті. 1941. № 14. С. 1-4.

\section{Література}

Вінницькі вісті. 1941. № 16. С. 1.

Вінницькі вісті. 1942. № 63. С. 2.

Вінницькі вісті. 1943. № 56. С. 3.

Военно-исторический журнал, 1960. № 1. С. 37-42.

Волинь. 1941. 12 вересня. С. 1.

Волинь. 1941. 26 жовтня. С. 4.

Волинь. 1941. 7 вересня. С. 3.

Волинь. 1942. 1 січня. С. 4.

Волинь. 1942. 12 лютого. С. 1.

Волинь. 1943. 25 листопада. С. 1.

Волковский Н.Л. История информационных войн. В 2 ч. Ч. 2. СПб. : 000 “Издательство “Полигон”, 2003. 729 с.

Гитлеровская пропаганда юдофобии в прокламациях и карикатуpax / С.Л. Авербух (сост. и авт. коммент.). К. : Украинский Центр изучения Холокоста, 2005. 224 с. 
Державний архів Вінницької області. Фонд Р-6022. - Колекція свідчень, спогадів та інших документів колишніх в'язнів гетто, концентраційних та робочих таборів, а також громадян, примусово вигнаних до Німеччини: Оп. 1. Спр. 13. 21 арк.

Державний архів Вінницької області. Фонд Р-6022. - Колекція свідчень, спогадів та інших документів колишніх в'язнів гетто, концентраційних та робочих таборів, а також громадян, примусово вигнаних до Німеччини: Оп. 2. Спр. 17. 37 арк.

Державний архів Сумської області (Далі - ДАСО). Фонд 1848 Редакція газети “Сумський вісник”, м. Суми Сумської області: Оп. 1. Спр. 2. 18 арк.

Державний Архів Харківської області: Фонд 2984 - Редакція газети “Нова Україна": Оп. 1. Спр. 1. 157 арк.

Державний Російський воєнний архів. Фонд 1358. Імперське міністерство у справах окупованих східних областей (м. Берлін), (Німецькі архіви. Трофейні документи): Оп. 1. Спр. 1. 89 арк.

Державний Російський воєнний архів. Фонд 1363 - Імперське міністерство просвіти і пропаганди (м. Берлін), (Німецькі архіви. Трофейні документи): Оп. 5, Спр. 56. 98 арк.

Допрос подсудимого Шпеера. Из стенограммы заседания Международного Военного Трибунала от 21 июня 1946 г. URL: http://historic.ru/books/item/f00/s00/z0000021/st018.shtml

Жадов A.C. Четыре года войны. URL: http://militera.lib.ru/memo/ russian/zhadov_as/05.html/

История Второй Мировой войны. В 12 т. Начало войны. Подготовка агрессии против СССР. 1939-1945. М. : Воениздат 1974. Т. 3. $498 \mathrm{c.}$

Нестеренко В.А. Аграрні перетворення окупаційних властей у військовій зоні України, 1941-1943 рр. Сторінки воєнної історії України : зб. наук. статей / НАН України. Ін-т історії України. К., 2004. Вип. 8. Част. 1. С. 279-298.

Німецько-фашистський окупаційний режим на Україні: Збірник документів і матеріалів. 1963. К. : Державне видавництво політичної літератури УРСР. 274 с.

Нове Запоріжжя. 1942. № 109. С. 4.

Нове Запоріжжя. 1942. № 88. С. 3, 4.

Салата 0.0. Значення економіки України у створенні оборонного потенціалу СРСР у період оборонних боїв (22 червня - грудень 1941 р.). К., 2005. 163 с. 
Сумський вісник. 1941. № 6. С. 2.

Сумський вісник. 1941. № 1. С. 1.

Центральний державний архів вищих органів влади та управління України: Фонд 2. - Рада міністрів України РСР: Оп. 2. Спр. 74. 12 арк.

Центральний державний архів вищих органів влади та управління України: Фонд 2. - Рада міністрів України РСР: Оп. 2. Спр. 68. 92. арк.

Центральний державний архів громадських об'єднань України: Фонд 1 - Центральний Комітет Комуністичної партії (більшовиків) України: Оп. 22. Спр. 390.97 арк.

Черняков Б. Окупаційна преса Рейхскомісаріату Україна: розбудова і функціонування (1941-1943рр.). Наукові записки. Збірник. К. : Інституту політичних і етнонаціональних досліджень ім. І.Ф. Кураса НАН України, 2006. С. 51-68. 